\title{
Storage Potential of Local Brazilian Pine Seed Varieties
}

\author{
Cristhyane Garcia Araldi ${ }^{1}$, Cileide Maria Medeiros Coelho' ${ }^{1}$, Marília Shibata ${ }^{2}$ \\ ${ }^{1}$ Departamento de Agronomia, Universidade do Estado de Santa Catarina - UDESC, Lages/SC, Brasil \\ ${ }^{2}$ Departamento de Fitotecnia, Universidade Federal de Santa Catarina - UFSC, Florianópolis/SC, Brasil
}

\begin{abstract}
Brazilian pine seeds (Araucaria angustifolia) are recalcitrant, and there are no studies evaluating the longevity of their different varieties. Our objective was to evaluate the capacity of different varieties of Brazilian pine seeds to maintain their physiological quality during storage. Seeds of the varieties: sancti josephi (I), angustifolia (II), caiova (III) and indehiscens (IV) were collected from two populations located in Santa Catarina, and stored under laboratory conditions and in a cold room for 90 days. On average, freshly harvested seeds showed $88 \%$ viability, and varieties II and III maintained the greatest viability (with the greatest vigor for variety II) after 90 days in storage. Varieties I and II maintained their pre-germinative metabolism for a longer period than the other varieties during storage. Therefore, seeds from the angustifolia variety (II) have higher storage potential than the other varieties, maintaining approximately $61 \%$ viability at 90 days of storage.
\end{abstract}

Keywords: viability, vigor, seed conservation. 


\section{INTRODUCTION}

Brazilian pine (Araucaria angustifolia (Bert) O. Ktze.) is the only species from the Araucariaceae family which naturally occurs in Brazil (Schlögl et al., 2012). The natural populations of the species are highly degraded and fragmented (Vibrans et al., 2011), hindering gene flow and favoring the occurrence of genetic erosion. It is estimated that between $2 \%$ to $12 \%$ of the original area with araucaria populations remains (in Brazil and Argentina) (Ribeiro et al., 2009), and approximately 7\% in Santa Catarina state (Vibrans et al., 2011). Therefore, Brazilian Pine is listed on the main Endangered species lists (Brasil, 2008; IUCN, 2013), and many efforts have been made to propagate and conserve the species (Balbuena et al., 2011).

Brazilian pine seeds are recalcitrant and have short longevity under natural conditions, reaching a maximum of six months (Fowler et al., 1998; Garcia et al., 2014; Pieruzzi et al., 2011), which makes it difficult to implement measures that seek to restore degraded populations. Several efforts have been made to investigate methods that extend the storage life of Brazilian pine seeds (Amarante et al., 2007; Caçola et al., 2006; Fowler et al., 1998; Piriz Carrillo et al., 2003). It is believed that seeking varieties whose seeds have superior longevity is an alternative for developing seed conservation technologies.

The first reports regarding the identification of Brazilian pine botanical varieties were made by Reitz \& Klein (1966), who reported the existence of nine varieties: elegans, sancti josephi, angustifolia, caiova, indehiscens, nigra, striata, semi-alba and alba. According to Mattos (2011), however, the species presents five varieties: angustifolia, indehiscens, caiova, dependens and vinacea, in addition to the catharinensis variety. With the help of farmers from Três Barras in Santa Catarina, Zechini et al. (2012) recognized four local varieties: sancti josephi, angustifolia, caiova and indehiscens. Recently, local extractors from Urubici and Painel identified a total of 11 local ethnovarieties (Adan et al., 2017).

These varieties mainly differ depending on the coloration and maturation season of the pine nuts. The sancti josephi variety has an early maturation season (February-March), popularly known (in Brazil) as "São José" (Reitz \& Klein, 1966; Zechini et al.,
2012) or " 25 de Março". The angustifolia variety is known as "comum" or "meia estação". Its seeds ripen between the months of April and May, and they are most commonly found by farmers in Santa Catarina (Zechini et al., 2012). Caiova or "kayuvá" variety as it is known, generally has larger pine nuts (pinhão), which mature between June and August (Mattos, 2011; Zechini et al., 2012). The indehiscens or "macaco" variety start their maturation season in August (and may occur until January), however its main characteristic is the fact that the seeds do not release from the female strobili/cone when ripe, and they remain attached to the parent tree (Reitz \& Klein, 1966; Mattos, 2011; Zechini et al., 2012).

Despite few reports in the literature that identify the different varieties of Brazilian pine, some studies have been recently developed aiming to characterize (Zechini et al., 2012) and evaluate the initial growth of the varieties (Coutinho \& Dillenburg, 2010). However, there are no reports of studies evaluating the physiological quality and storage potential of the different varieties. Thus, the objective of this study was to evaluate the seed behavior of different Brazilian pine varieties in terms of maintaining physiological quality during storage, aiming to prolong the seed availability period for the purposes of utilization and conservation.

\section{MATERIAL AND METHODS}

Local varieties of Araucaria angustifolia were identified based on farmer observation and according to the maturation season of the pine cones (pinhas), corresponding to the varieties: I - "sancti josephi", known as "25 de março"; II - "angustifolia", or "comum" or "meia estação"; III - "caiova", or "kayuvá"; IV - "indehiscens", or "macaco". Mature seeds from the four varieties were collected from two natural populations located in the municipalities of Painel and Urubici - Santa Catarina, corresponding to Lots 1 and 2 , respectively, from $15 \pm 3$ matrices/population. Collection was performed between the months of March and August, where cones (pinhas) with isolated spots or those grouped forming brown spots were considered mature (Mattos, 2011).

Seed samples from both lots and from the four varieties were individually homogenized and separated into four replications, and then submitted to storage 
conditions: natural laboratory environment and cold room (temperature of $10 \pm 3^{\circ} \mathrm{C}$ and relative air humidity of $45 \pm 5 \%$ ), in sealed plastic packages and in packages with a porosity of $0.015 \mu \mathrm{m}$. The laboratory environment condition was performed in the city of Lages (SC), as its climatological characteristics resemble those of the seed collection sites. As a reference, data from EPAGRI (2014) indicate temperature and relative humidity variation for the storage period (Table 1). Physiological quality evaluations were performed on freshly harvested seeds and after 30, 60 and 90 days of storage.

The degree of moisture was determined using four replications of three seeds cut transversely, according to the greenhouse method at $105^{\circ} \mathrm{C} \pm 3^{\circ} \mathrm{C}$ for 24 hours (Brasil, 2009). Seed germination was evaluated visually, considering emerged seeds as those that had a primary root visibly protruding (minimum of $5 \mathrm{~mm}$ ) still inside the plastic packaging during storage.

Seed viability was evaluated by $\mathrm{pH}$ exudate and tetrazolium tests, using 25 embryos per replication. The $\mathrm{pH}$ of the exudate was performed by individually immersing the embryos in $5 \mathrm{~mL}$ of water for 30 minutes at $25 \pm 1{ }^{\circ} \mathrm{C}$, followed by the addition of two drops of a sodium carbonate $(8 \mathrm{~g} / \mathrm{L})$ and phenolphthalein (5\%) solution (Araldi \& Coelho, 2015b). The tetrazolium test was performed by immersing the embryos in $0.1 \%$ tetrazolium solution at $25 \pm 1{ }^{\circ} \mathrm{C}$ for 1 hour (Oliveira et al., 2014). Viable embryo analysis was carried out by staining the soaking solution ( $\mathrm{pH}$ of the exudate) and tissue staining (tetrazolium), associating them with the extent and location of the damage.

Electrical conductivity was determined using 10 embryos per replication, soaked in $75 \mathrm{~mL}$ of distilled water and maintained at $25 \pm 1{ }^{\circ} \mathrm{C}$ for 12 hours (Medeiros \& Abreu, 2007). The electrical conductivity of the solution was measured using a portable Quimis
QQ95 conductivity meter, and the results expressed as $\mu \mathrm{S} . \mathrm{cm}^{-1} \cdot \mathrm{g}^{-1}$ of embryos.

The experiment was carried out according to a completely randomized design. The data were submitted to the normality test and transformed in arcsine $\sqrt{ } \%$, followed by analysis of variance to detect differences between the lots; and then grouped in the storage period as sub-divided parcels. Means separation was performed using the SNK test at 5\% probability, and regression analysis using the SAS statistical program (SAS, 2009).

\section{RESULTS AND DISCUSSION}

In freshly harvested seeds, it was possible to observe differences regarding the degree of moisture $(\mathrm{P} \leq 0.05)$ between the varieties (Figure 1A, B), ranging from $53.1 \%$ (variety I) to $48.7 \%$ (variety III). Moisture reduction during storage only occurred for varieties III and IV for both storage conditions. No significant interaction $(\mathrm{P} \leq 0.05)$ between the varieties and the storage conditions were observed for seed moisture.

Some researchers indicate that the lethal level of moisture for Brazilian pine seeds is between 25 and 38\%, meaning that there would be a total loss of viability below this threshold (Eira et al., 1994; Espindola et al., 1994). Only seeds from variety IV stored for 90 days under laboratory conditions had their moisture content reduced to values within this threshold, at $34.6 \%$.

Brazilian pine seeds remain metabolically active during storage, and present changes associated with the germination process (Amarante et al., 2007; Araldi \& Coelho, 2015a); a characteristic that constitutes the basis of its recalcitrant behavior (Pammenter \& Berjak, 2013). In fact, seed germination

Table 1. Reference temperature and relative humidity for the storage period of Araucaria angustifolia seeds from varieties I (sancti Josephi), II (angustifolia), III (caiova) and IV (indehiscens), according to EPAGRI (2014).

\begin{tabular}{|c|c|c|c|c|c|c|}
\hline \multirow{2}{*}{ Variety } & \multicolumn{3}{|c|}{ Temperature $\left({ }^{\circ} \mathrm{C}\right)$} & \multicolumn{3}{|c|}{ Relative humidity (\%) } \\
\hline & Mean & Maximum & Minimum & Mean & Maximum & Minimum \\
\hline I & 11.7 & 24.8 & -1.8 & 85 & 98 & 35 \\
\hline II & 12.1 & 25.6 & -1.8 & 85 & 99 & 44 \\
\hline III & 13.0 & 29.2 & -1.5 & 82 & 99 & 39 \\
\hline IV & 15.1 & 29.2 & -1.5 & 81 & 99 & 39 \\
\hline
\end{tabular}



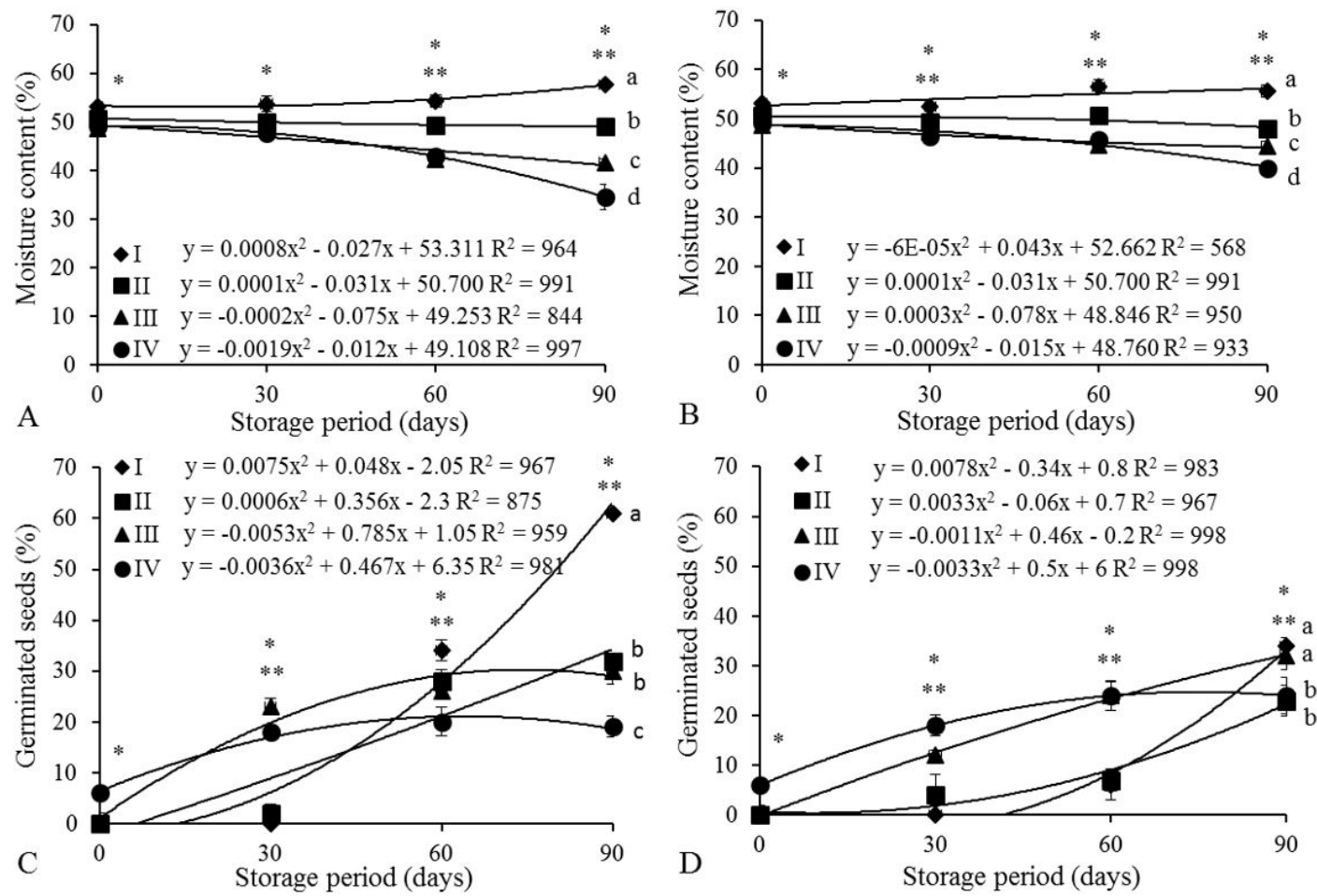

Figure 1. Moisture content of Araucaria angustifolia seeds from varieties I (sancti Josephi), II (angustifolia), III (caiova) and IV (indehiscens) during storage under laboratory environment conditions (A) and cold chamber (B), and germinated seeds upon storage under laboratory environment conditions (C) and cold chamber (D). The letters refer to the means separation by SNK test $(\mathrm{P} \leq 0.05)$ and compare the varieties. ${ }^{*}$ Indicates significant differences $(\mathrm{P} \leq 0.05)$ for at least one variety in relation to others; ${ }^{* \star}$ Indicates significant differences $(\mathrm{P} \leq 0.05)$ between the storage period in relation to the previous period, for at least one variety.

under storage was observed inside the plastic package. For freshly harvested seeds, only variety IV presented germinated seeds (6\%) (Figure 1C, D). At 30 days of storage, only varieties III and IV presented germinated seeds for both storage conditions, while varieties I and II maintained their pre-germinative metabolism. Although variety I seed germination occurred at later stages of storage (at 60 days) in relation to the others, this variety showed the highest percentages of germinated seeds at 90 days of storage for both conditions. This result can be correlated to the higher moisture content presented by this variety at 90 days of storage.

Regarding storage conditions, it was possible to observe significant differences $(\mathrm{P} \leq 0.05)$ at 60 and 90 days; however, these discrepancies are due to a higher percentage of germinated seeds in the laboratory environment, mainly observed in variety I. Some authors observed a positive correlation between Brazilian pine germination and temperature during storage, up to a limit of $20^{\circ} \mathrm{C}$
(Amarante et al., 2007). Under cold room conditions $\left(10^{\circ} \mathrm{C}\right), 23$ to $34 \%$ of germinated seeds were observed at 90 days, varying between the varieties. At temperatures of $10{ }^{\circ} \mathrm{C}$, other authors observed $21 \%$ germination at 90 days of storage (Amarante et al., 2007), and $24 \%$ germination at 120 days at a temperature of $5{ }^{\circ} \mathrm{C}$ (Garcia et al., 2014).

The mean viability oh the freshly harvested seeds was $85 \%$ (pH exudate) and 91\% (tetrazolium), without significant differences $(\mathrm{P} \leq 0.05)$ between the varieties (Figure 2). A reduction in viability was observed for all varieties within the 90-day period, regardless of the storage condition. Only varieties II and III (for laboratory storage) and variety II (for cold room storage) presented significantly higher viability than the others $(\mathrm{P} \leq 0.05)$ at 90 days for both viability tests ( $\mathrm{pH}$ of exudate and tetrazolium). By calculating an average of the viability tests, it could be observed that the viability of Brazilian pine seeds can be maintained 

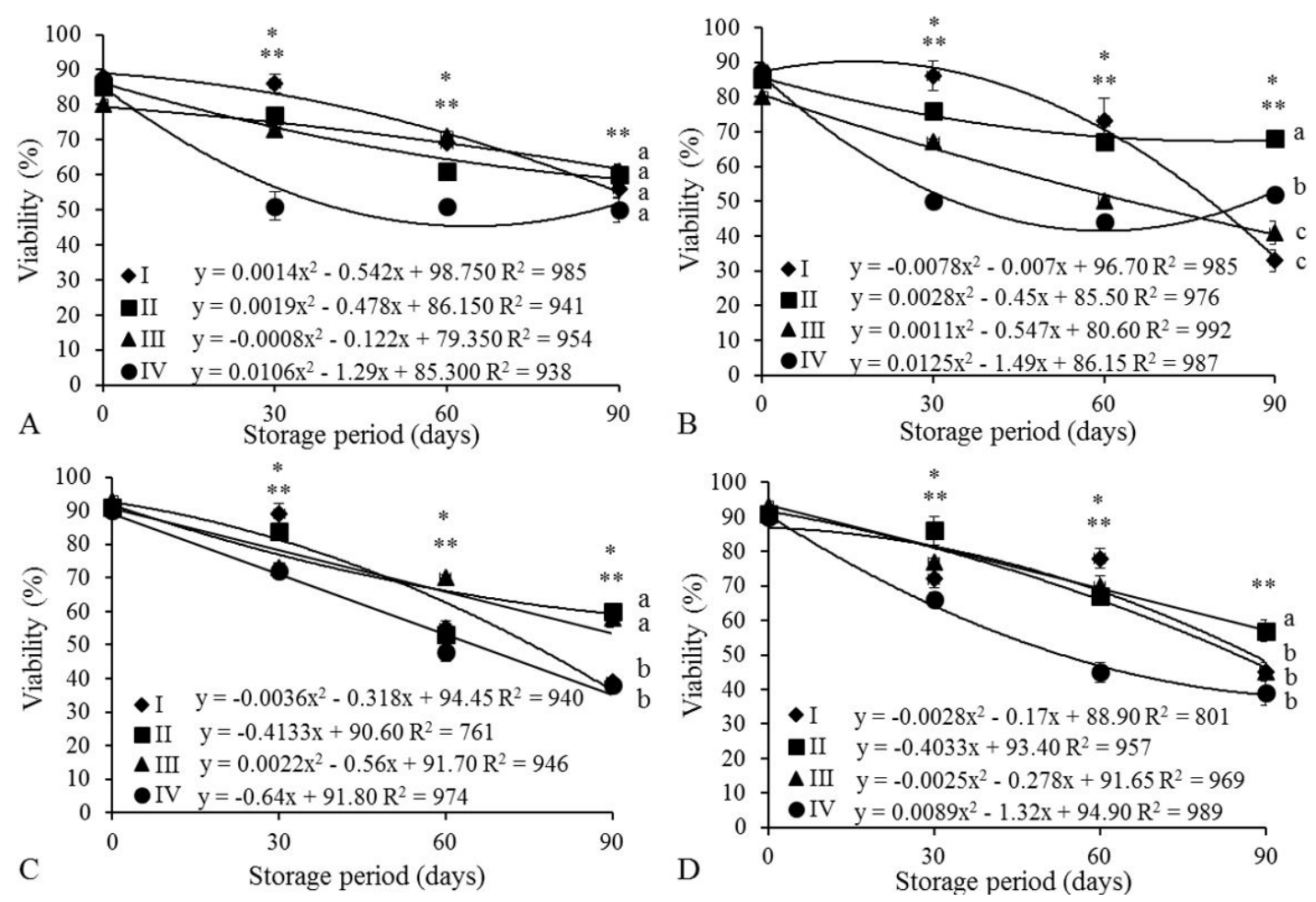

Figure 2. Viability of Araucaria angustifolia seeds from varieties I (sancti Josephi), II (angustifolia), III (caiova) and IV (indehiscens) evaluated by $\mathrm{pH}$ exudate test during storage under laboratory environment conditions (A) and cold chamber (B), and by tetrazolium test under laboratory environment conditions (C) and cold chamber (D) conditions. The letters refer to the means separation by SNK test $(\mathrm{P} \leq 0.05)$ and compare the varieties. ${ }^{*}$ Indicates significant differences $(\mathrm{P} \leq 0.05)$ for at least one variety in relation to the others; ${ }^{* *}$ Indicates significant differences $(\mathrm{P} \leq 0.05)$ between the storage period in relation to the previous period, for at least one variety.

around $60 \%$ (variety II) and 59\% (variety III) in a laboratory environment at 90 days of storage, and $62 \%$ (variety II) in cold room conditions, meaning that these varieties present greater storage potential under the temperature and humidity conditions tested.

In fact, seeds from variety IV stored for 90 days in ambient conditions (34.6\% humidity) presented the lowest percentage of viability (on average $44 \%$, $\mathrm{pH}$ of exudate and tetrazolium). However, this value was not significantly different $(\mathrm{P} \leq 0.05)$ from the viability of varieties I, II and III (pH of the exudate), and variety I (tetrazolium) at 90 days of storage, nor did it differ from the viability presented by this variety (IV) at 90 days of storage in a cold room (on average $45 \%$, with $39.8 \%$ humidity). Therefore, these results indicate that changes in viability resulting from desiccation would be more pronounced in more advanced stages of water loss.

Electrical conductivity provided indications of vigor between the varieties and during storage. Lower electrical conductivity values occurred for varieties I, II and III (Lot 1, conductivity of 51.44; 56.48 and $61.34 \mu \mathrm{S} . \mathrm{cm}^{-1} . \mathrm{g}^{-1}$, respectively), and II (Lot 2, conductivity of $45.79 \mu \mathrm{S} . \mathrm{cm}^{-1} \cdot \mathrm{g}^{-1}$ ) in freshly harvested seeds (Table 2), indicating that regardless of origin, the variety II seeds potentially have a high vigor. In general, the electrical conductivity of the samples increased during storage, especially for variety IV (conductivity greater than $191.20 \mu \mathrm{S} . \mathrm{cm}^{-1} \cdot \mathrm{g}^{-1}$ ), regardless of lot and storage condition, indicating that this variety shows less vigor in relation to the others.

By reaching physiological maturity, the seeds usually reach their maximum vigor, and its decrease during storage reflects the hydrolysis of the accumulated reserves in the seed, resulting from the respiratory and consumption activities in the pre-germination process (Guedes et al., 2013). In fact, an increase in respiratory activity of Brazilian pine seeds during storage was observed at 90 days under the temperature of $10{ }^{\circ} \mathrm{C}$ (Amarante et al., 2007). 
Table 2. Electrical conductivity $\left(\mu \mathrm{S} . \mathrm{cm}^{-1} \cdot \mathrm{g}^{-1}\right)$ of Araucaria angustifolia embryos from varieties I (sancti Josephi), II (angustifolia), III (caiova) and IV (indehiscens), from lots 1 and 2 during storage.

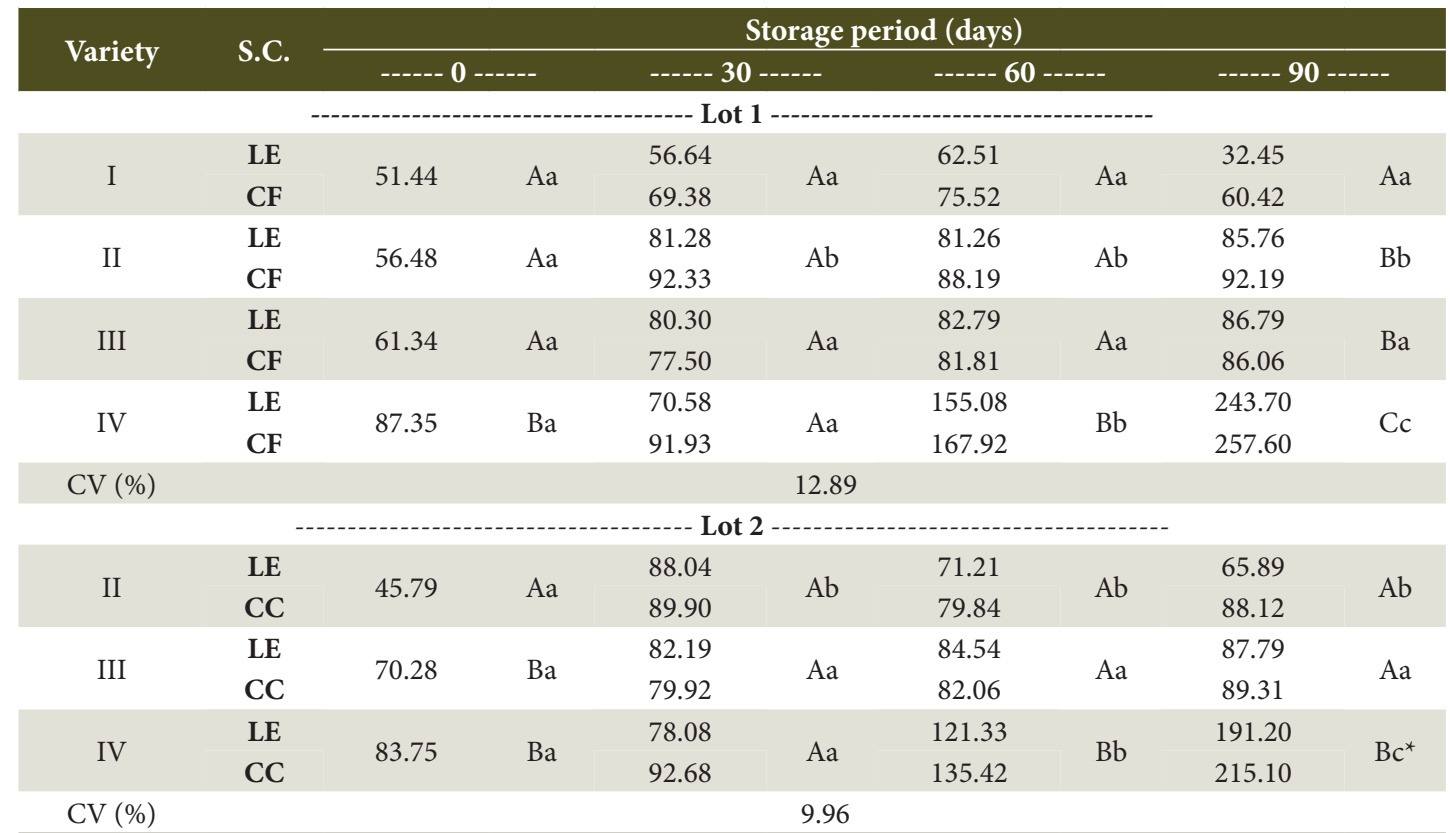

The letters refer to the means separation by SNK test $(\mathrm{P} \leq 0.05)$ and compare: varieties in the column (uppercase); storage periods in the line (lowercase); ${ }^{\star}$ Indicates significant differences between storage conditions (SNK test; P $\leq 0.05$ ). S.C. - storage condition; LE - laboratory environment; CC - cold chamber.

With the exception of variety IV from Lot 2, no differences between storage conditions were found for conductivity results. In comparing the lots, it was observed that on average Lot 2 presented lower solute leaching $(\mathrm{P} \leq 0.05)$, and therefore higher vigor.

Viability and vigor results were generally higher for variety II. Such results seem to influence the growth of seedlings, since the angustifolia variety (variety II) presented superior growth in comparison to the caiova and indehiscens varieties (Coutinho \& Dillenburg, 2010). Additionally, variety II seeds had a slower germination process, with the occurrence of germination under storage only after 30 days, indicating that this variety could be kept longer than the others. This is because once the germination begins during storage of recalcitrant seeds, there is a gradual increase in the metabolic activity and additional water for the tissues will be required. If the conditions are not ideal for completing the process (as in the case of the seeds that remain stored), deterioration will commence (Pammenter \& Berjak, 2013; Walters, 2015). Therefore, Brazilian pine seeds that maintain pre-germinative metabolism for longer can be stored for a longer period (Araldi \& Coelho, 2015a).

The total time elapsed during seed development seems to contribute to the discrepancies observed between the varieties, since pollination occurs from September to October for all varieties, while seed maturation generally occurs between March and August (Mattos, 2011; Zechini et al., 2012). This fact may have contributed to the variety I seeds, which mature in March, presenting higher humidity due to early maturation. In seeds from variety IV on the other hand, in which maturity occurs in July/August, the seed development period is longer, and consequently the seeds are more exposed to climatic variability and possible loss of vigor.

With a view towards species conservation and maintaining genetic diversity, we emphasize the importance of using other varieties, either for food purposes or for seedling production. Further experiments should be conducted to improve management and promote the use and conservation of the species. 


\section{CONCLUSION}

Mature Brazilian pine seeds present viability above $80 \%$ when freshly harvested, regardless of the variety; however, angustifolia (II) seeds presented the greatest vigor. Angustifolia (II) seeds had the greatest storage potential in relation to the other varieties (sancti josephi, caiova and indehiscens), maintaining $60 \%$ viability at 90 days storage under ambient conditions, and $62 \%$ under cold room conditions.

\section{ACKNOWLEDGEMENTS}

C. G. Araldi wishes to thank the Fundação de Amparo à Pesquisa e Inovação do Estado de Santa Catarina (FAPESC) for providing a PhD scholarship. C. M. M. Coelho would like to thank the Conselho Nacional de Desenvolvimento Científico e Tecnológico (CNPq) for the research productivity fellowships granted.

\section{SUBMISSION STATUS}

Received: 6 nov., 2015

Accepted: 18 apr., 2017

\section{CORRESPONDENCE TO}

\section{Cristhyane Garcia Araldi}

Departamento de Agronomia, Universidade do Estado de Santa Catarina - UDESC, Av. Luís de Camões, 2090, Conta Dinheiro, CEP 88520-000, Lages, SC, Brazil

e-mail: cristhyane.araldi@udesc.br

\section{REFERENCES}

Adan N, Atchison J, Reis MS, Peroni N. Local knowledge, use and management of ethnovarieties of Araucaria angustifolia (Bert.) Ktze. in the Plateau of Santa Catarina, Brazil. Economic Botany 2017; 71(2): 200. http://dx.doi. org/10.1007/s12231-017-9376-0.

Amarante CVT, Mota CS, Megguer CA, Ide GM. Conservação pós-colheita de pinhões [sementes de Araucaria angustifolia (Bertoloni) Otto Kuntze] armazenados em diferentes temperaturas. Ciência Rural 2007; 37(2): 346-351. http:// dx.doi.org/10.1590/S0103-84782007000200008.

Araldi CG, Coelho CMM. Establishment of post-harvest early-developmental categories for viability maintenance of Araucaria angustifolia seeds. Acta Botanica Brasílica 2015a; 29(4): 524-531. http://dx.doi.org/10.1590/0102$33062015 a b b 0061$.

Araldi CG, Coelho CMM. pH do exsudato na avaliação da viabilidade de sementes de Araucaria angustifolia. Floresta e Ambiente 2015b; 22(3): 426-433. http://dx.doi. org/10.1590/2179-8087.082314.

Balbuena TS, Jo L, Pieruzzi FP, Dias LLC, Silveira V, Santa-Catarina $C$ et al. Differential proteome analysis of mature and germinated embryos of Araucaria angustifolia. Phytochemistry 2011; 72(4-5): 302-311. PMid:21276992. http://dx.doi.org/10.1016/j.phytochem.2010.12.007.

Brasil. Ministério da Agricultura, Pecuária e Abastecimento - MAPA. Regras para análise de sementes. Brasília: MAPA/ ACS; 2009.

Brasil. Ministério do Meio Ambiente. Instrução normativa $n^{\circ} 6$, de 23 de setembro de 2008. Lista oficial das espécies da flora brasileira ameaçadas de extinção [online]. Diário Oficial da República Federativa do Brasil, Brasília, DF (2008 set.). [cited 2015 Nov 6]. Available from: http://www.mma. gov.br/estruturas/179/_arquivos/179_05122008033615.pdf Caçola ÁV, Amarante CVT, Fleig FD, Mota CS. Qualidade fisiológica de sementes de Araucaria angustifolia (Bertol.) Kuntze submetidas a diferentes condições de armazenamento e a escarificação. Ciência Florestal 2006; 16(4): 391-398. http://dx.doi.org/10.5902/198050981920.

Coutinho AL, Dillenburg LR. Comparison of seedling growth among three co-occurring varieties of Araucaria angustifolia (Bertol.) Kuntze under greenhouse conditions. Acta Botanica Brasílica 2010; 24(2): 567-570. http://dx.doi. org/10.1590/S0102-33062010000200025.

Eira MTS, Salomão AN, Cunha R, Carrara DK, Mello CMC. Efeito do teor de água sobre a germinação de sementes de Araucaria angustifolia (Bert.) O. Ktze - Araucariaceae. Revista Brasileira de Sementes 1994; 16(1): 71-75. http:// dx.doi.org/10.17801/0101-3122/rbs.v16n1p71-75.

Empresa de Pesquisa Agropecuária e Extensão Rural de Santa Catarina - EPAGRI. Centro de Informações de Recursos Ambientais e de Hidrometeorologia de Santa Catarina - CIRAM. Climatological atlas of Santa Catarina State [online]. Florianópolis: EPAGRI; 2014 [cited 2015 Nov 6]. Available from: http://ciram.epagri.sc.gov.br

Espindola LS, Noin M, Corbineau F, Côme D. Cellular and metabolic damage induced by desiccation in recalcitrant Araucaria angustifolia embryos. Seed Science Research 1994; 4(02): 193-201. http://dx.doi.org/10.1017/ S096025850000218X.

Fowler JAP, Bianchetti A and Zanon A. Conservação de sementes de pinheiro-do-Paraná sob diferentes condições de ambientes e embalagens. Colombo: Embrapa; 1998. p. 1-4. (Comunicado Técnico; no. 34).

Garcia C, Coelho CMM, Maraschin M, Oliveira LM. Conservação da viabilidade e vigor de sementes de Araucaria angustifolia (Bert.) O. Kuntze durante o 
armazenamento. Ciência Florestal 2014; 24(4): 857-866. http://dx.doi.org/10.5902/1980509816586.

Guedes RS, Alves EU, Costa EMT, Santos-Moura SDS, da Silva RDS, Cruz FRDS. Avaliação do potencial fisiológico de sementes de Amburana cearensis (Allemão) A.C. Smith. Bioscience Journal 2013; 29(4): 859-866.

International Union for Conservation of Nature - IUCN. IUCN Red List of Threatened Species. Version 2013.2. Gland: IUCN; 2013 [cited 2015 Nov 6]. Available from: http://www.iucnredlist.org

Mattos JR. O pinheiro brasileiro. Florianópolis: UFSC; 2011.

Medeiros ACS, Abreu DCA. Desidratação ultra-rápida de embriões. Pesquisa Florestal Brasileira 2007; 54: 119-125.

Oliveira LM, Gomes JP, Souza GK, Nicoletti MF, Liz TO, Pikart TG. Metodologia alternativa para o teste de tetrazólio em sementes de Araucaria angustifolia (Bertol. ) Kuntze. Floresta e Ambiente 2014; 21(4): 468-474. http:// dx.doi.org/10.1590/2179-8087.064413.

Pammenter NW, Berjak P. Development of the understanding of seed recalcitrant and implications for ex situ conservation. Biotecnologia Vegetal 2013; 13(3): 131-144.

Pieruzzi FP, Dias LLC, Balbuena TS, Santa-Catarina C, Santos AL, Floh EI. Polyamines, IAA and ABA during germination in two recalcitrant seeds: Araucaria angustifolia (Gymnosperm) and Ocotea odorifera (Angiosperm). Annals of Botany 2011; 108(2): 337-345. PMid:21685432. http://dx.doi.org/10.1093/aob/mcr133.

Piriz Carrillo V, Chaves A, Fassola H, Mugridge A. Refrigerated storage of seeds of Araucaria angustifolia (Bert.) O. Kuntze over a period of 24 months. Seed Science and Technology 2003; 31(2): 411-421. http://dx.doi. org/10.15258/sst.2003.31.2.18.
Reitz R, Klein RM. Araucariáceas. In: Reitz R, editor. Flora ilustrada Catarinense. Itajaí: Herbário Barbosa Rodrigues; 1966.

Ribeiro MC, Metzger JP, Martensen AC, Ponzoni FJ, Hirota MM. The Brazilian Atlantic Forest: How much is left, and how is the remaining forest distributed? Implications for conservation. Biological Conservation. Elsevier Ltd 2009; 142(6): 1141-1153. http://dx.doi.org/10.1016/j. biocon.2009.02.021.

SAS Institute Inc. - SAS. SAS statistical program. Cary: SAS; 2009.

Schlögl PS, Santos ALW, Vieira LN, Floh EIS, Guerra MP. Cloning and expression of embryogenesis-regulating genes in Araucaria angustifolia (Bert.) O. Kuntze (Brazilian Pine). Genetics and Molecular Biology 2012; 35(1): 172 181. PMid:22481892. http://dx.doi.org/10.1590/S141547572012005000005 .

Vibrans AC, Sevegnani L, Uhlmann A, Schorn LA, Sobral MG, de Gasper AL et al. Structure of mixed ombrophyllous forests with Araucaria angustifolia (Araucariaceae) under external stress in Southern Brazil. Revista de Biología Tropical 2011; 59(3): 1371-1387. PMid:22017139.

Walters C. Orthodoxy, recalcitrance and in-between: describing variation in seed storage characteristics using threshold responses to water loss. Planta 2015; 242(2): 397-406. http://dx.doi.org/10.1007/s00425-015-2312-6.

Zechini AA, Schussler G, Silva JZ, Mattos AG, Peroni N, Mantovani A et al. Produção, comercialização e identificação de variedades de pinhão no entorno da Floresta Nacional de Três Barras - SC. Biodiversidade Brasileira 2012; 2(2): 74-82. 